\title{
The World, the Flesh and the Devil: the Life and Opinions of Samuel Marsden in England and the Antipodes, 1765-1838
}

Review Number: 2156

Publish date: Thursday, 24 August, 2017

Author: Andrew Sharp

ISBN: 9781869408121

Date of Publication: 2016

Price: $£ 69.50$

Pages: 928pp.

Publisher: Auckland University Press

Publisher url: http://www.press.auckland.ac.nz/en/browse-books/all-books/books-2016/the-world--the-flesh-and-the the-life-and-opinions-of-sam.html

Place of Publication: Auckland

Reviewer: Ged Martin

Samuel Marsden was a Yorkshireman of humble origins (as his detractors liked to point out). After a brief spell at Cambridge, in 1793 he was appointed the second official Anglican chaplain in the recently established convict colony of New South Wales. In 1814, he took the Gospel to New Zealand. He was a controversial figure in his lifetime, and - as Andrew Sharp demonstrates in a supplementary essay - his posthumous reputation has also suffered. The author suggests that this very long book may be treated either as continuous analysis or as a series of discrete chapters. It will certainly remain a major source for the study of Marsden, but Sharp's approach leaves space for alternative interpretations. Auckland University Press must be congratulated on their handsome production, including - a helpful (and faintly Biblical) touch - the inclusion of two marker ribbons, enabling readers to keep their places in both text and endnotes. (Sharp italicises every quotation from Scripture in his extensive extracts from Marsden's writings, adding chapter and verse in square brackets. At first, I feared that this might be intrusive, but it did not prove so.)

The illustrations, mostly in colour, include a portrait of Marsden at about the age of 40, which did not appear in A. T. Yarwood's 1977 biography (1), the study that has held the Marsden field to date. The two portraits previously in circulation showed him in later life, with - as one historian put it - 'the face of a petulant ox' (p. 776). This 1809 engraving (facing p. 504) suggests a more appealing personality, no doubt intended to project him as a missionary hero. The discovery is reminder that we should be wary about inferring character from historical portraits, especially those from untalented artists.

Sharp argues that it takes 'a considerable effort of the historical imagination' (p. 6) to reconstruct the mental universe within which Marsden responded to the challenges and opportunities he faced. In relation to New Zealand, for instance, historians have appreciated for more than half a century that the Maori universe, so shocking to Europeans, was shaped by highly nuanced ideas of spirituality and social relationships. Sharp pertinently adds that we have lost not one, but two worlds. We need to recover a lost Western cosmology, spurred by Marsden's own terrified conviction that his soul, everybody's soul, faced a triple challenge, from the World, the Flesh and the Devil. Hence Sharp announces that he does not seek to offer judgement, that he is 'respectful' (p. 6) of Marsden's opinions, and that his subject's life and work 'should as much as possible 
speak for themselves through his letters, books, and public statements, and be discerned in his actions.' (p. 7) It is here that a reviewer may begin to feel some concerns, first because allowing Marsden to speak for himself tends to mean dismissing the comments of his critics, and, second, because some of Marsden's actions are capable of creating a troubling impression, arguably even by the standards of his era.

The Evangelicals of the Elland Society sent Marsden to school in Kingston-upon-Hull as preparation for Cambridge. Although duly noted, their choice of college, Magdalene, then the stronghold of advanced Protestantism in the University, might have received greater emphasis. It emerges only 100 pages later that the Reverend Richard Johnson, whom Marsden joined in New South Wales, was a product of the same college. The Master of Magdalene, Peter Peckard, whose denunciations of slavery had kick-started the campaign for emancipation, is mentioned briefly when Marsden encountered slaves at landfalls during his outward voyage. Marsden also probably knew a slightly earlier Hull and Magdalene student, John Crowther, who had failed to reach New South Wales in 1790.

Magdalene was not only a missionary college, it was also 'Methodistical', in the terms of contemporary vituperation. John Wesley died in March 1791; Marsden was in Cambridge from late 1790 until mid-1792, right on the cusp of the final break between Anglicans and Wesleyans. Throughout his first 30 years in New South Wales, he would operate at some remove from Church of England structures. The 'Methodist' tag would occasionally hover around him, but it seems fairer to see Marsden as a strong upholder of Anglican authority even though he had been moulded in an era of denominational transition.

Marsden arrived in New South Wales in 1794, at a formative moment in the colony's early development. The idealistic Arthur Phillip, the colony's first governor, had departed in 1792, leaving the garrison commander France Grose in charge. Although often viewed merely as a two-year interregnum, Grose's brief tenure was in fact important in determining Australia's longer-term development. He granted land to fellow officers, and assigned them convicts, fed at public expense, to develop their holdings. Thus began a distinctively Australian form of political economy, whereby resources were handed over to private ownership, which in turn demanded that public enterprise subsidise their exploitation. Moreover, neither Grose nor his successor, Governor Hunter, regarded church-building as a priority. Thus the timing of Marsden's arrival was important for the choices he had to make.

Essentially, Sharp accepts Marsden's decisions. Here is the author's remarkably succinct comment on the crucial first six years in the colony. 'Under Grose and Hunter from 1794 to 1800, with the governing powers successively hostile to religion or incapable of helping its spread, there was little for it but that Marsden turn his abundant but frustrated energies elsewhere: to farming and to the calling of the magistracy' (p. 154). Sharp adds that this followed the example of Johnson, and that he consulted his allies in England - who, months away by mail, tended to acquiesce in moves that their distant chaplain had already made. Marsden himself made the not-unreasonable point that the colony had been on the verge of starvation, and that if he had refused the 100-acre land grant offered to him, people 'would have said the clergyman is an idle, lazy fellow, and will do nothing towards maintaining himself and family' (p. 154). 
All of that is fair enough, but surely Sharp's formula, 'little for it', slips far too easily into acceptance of Marsden's decision to embrace large segments of the World that he professed to resist? Marsden hardly faced martyrdom during his early years in New South Wales. The authorities were unsympathetic, but many religious figures have faced discouragement. Other strategies were open to him - counselling and catechism, preaching and prayer. Part of the problem was, no doubt, environmental as much as ethical. Phillip's experiment with English-style cottage allotments had demonstrated that Australia was a country where only large-scale farming would produce worthwhile results, especially when sheep became the focus of rural industry. By 1804, Governor King could call Marsden the 'best practical farmer in the colony' (p. 202). 'Nothing was out of order in the chaplain's behaviour', Sharp insists (p. 154). However, he went far beyond contributing to basic subsistence. By 1804, he was the 12th largest landowner in New South Wales. 'I may be too fond perhaps of the garden, the field and the fleece', Marsden conceded in 1811 (p. 360). This is more than his biographer seems willing to admit.

Marsden is remembered as the clerical magistrate who became notorious as a flogging parson, and this has led him being regarded with distaste by many historians. As Sharp puts it in an aside, 'according to some ways of seeing things' (p. 236), Marsden should have distanced himself from law enforcement, and 'have had no part in corporal punishment' (p. 236). Here, it may certainly be conceded that there is a case for the defence. Clergy acted as magistrates in England, where flogging was a legal punishment, if not as routinely and brutally imposed as in New South Wales. Corporal punishment was taken for granted in the Bible. As chaplain, Marsden was part of the military establishment. He believed in obedience, and Governor Hunter wanted him in the job. Marsden's clerical duties included accompanying convicts to the gallows, so he could hardly distance himself entirely from law enforcement. Taking the matter one step at a time, it is indeed possible to see how the idealistic young clergyman of 1794 could become the stern magistrate of 1795 and after.

And yet, it could have been different, and surely it is a biographer's task to set the path chosen against the alternatives that might have beckoned? Marsden himself acknowledged that his Evangelical backers had 'advised me much against acting as a magistrate', and he himself was 'not without my doubts' that the role was incompatible with his calling as a clergyman (p. 157). Much obviously depended upon the specific circumstances of the remote penal settlement. It is possible to proclaim that Charles Simeon or John Wesley would never have accepted a judicial role in a gulag, but Charles Simeon and John Wesley (who did keep clear of government during his two-year stint in Georgia) were unlikely to have been sent to Botany Bay. But there is no evidence that Marsden asked Governor Hunter to exempt him from the magistracy. It is also the case that once he became the recipient of assigned convict labourers to work his land grants, he needed judicial authority to control them.

Marsden claimed that he accepted appointment to the Bench partly to mitigate abuses. But, by 1822 , investigating commissioner J. T. Bigge could report that his sentences were 'more severe than those of other Magistrates', and that 'the general opinion in the Colony' was that Marsden's character was 'stamped with severity' (p. 502). Sharp responds to such charges in two ways. One is to examine the few specific cases where records prove that Marsden sat. He pronounces that the chaplain's floggings were 'remarkably mild', not exceeding 50 lashes (p. 239). This value judgement is based on two issues of the Sydney Gazette in 1805-6, which seems a narrow basis of evidence. For instance, the same newspaper, on 16 September 1826 - after Bigge's condemnation - reports Marsden having sentenced two delinquent convicts to repeated impositions of 25 lashes, one on a weekly basis until stolen property was returned, the other (who was to be fed on bread and water) every morning until he identified participants in a gambling den. Such punishments may have been seen as necessary in the artificial society of New South Wales, but floggings designed to force disclosures can hardly be termed mild.

More broadly, Sharp challenges the way in which historians interpret evidence, warning against the view that the presence of smoke must imply fire. It is true that, in the poisonous atmosphere of early New South Wales, false allegations were rife. For instance, Governor Lachlan Macquarie, appointed in 1809, believed 
that Marsden had 'repeatedly visited his Native Country' (p. 481). In fact, there had been one return trip, from 1807 to 1809 . But it still seems a large jump to dismiss as 'calumnies ... partisan argument' all contemporary criticism, 'quite leaving aside his character in the world as he himself and his friends saw it' (pp. 442-3). Nor is it consistent for Sharp to argue that 'no one plausibly accused him [Marsden] of gluttony, drunkenness or sexual impropriety, even when it was in their greatest interest to do so' (p. 765). It seems that absence of allegations is treated as evidence of the proof of virtue, while charges of personal failings are dismissed as manifestations of malice. In any case, the criticisms of others count little alongside Marsden's own interpretations of his motives. He saw 'nothing eccentric or unjustifiable' about his combination of roles (p. 443). He 'neither quoted scripture nor in any way theorised about corporal punishment or the death sentence. He saw no need to ask himself why he did what he did' (p. 256).

By no means all the stories of Marsden the flogger were told to discredit him. It was a favourable source who supplied the tale of a free settler whose ex-convict bride mocked her husband's pleas that she should cook or clean. Guided by the Biblical injunction that wives must obey their husbands, Marsden broke her resistance with his horsewhip. In contemporary values, the story had a happy ending, with the grateful husband assuring the chastiser, 'thanks to you sir, there cannot be a better wife now, she is everything I can wish' (p. 665). Marsden here is the hero of the one of the classic narratives of our culture, the maiming of the shrew.

Several themes fuse together in the affair of the Hawkesbury turnpike trust. When Governor Macquarie arrived in New South Wales, two decades after its foundation, the penal colony contained a growing number of 'emancipists', convicts who had served their terms but preferred to prosper in the colony rather than return to Britain. Macquarie began a policy of appointing the more successful ex-convicts to official jobs. In 1810 , Marsden was informed of his appointment as a commissioner for the construction of a highway to the outlying settlements on the Hawkesbury river. When he discovered that he was to share the responsibility with two entrepreneurial emancipists, Marsden strongly objected to their criminal pasts and to the fact that both were living in sin. Relations with Macquarie were fatally damaged.

The problem with Marsden's principled stand was that it was inconsistent. As he himself insisted, stressing the virtues of obedience: 'whenever the Governor thought Proper to call a meeting of the Magistrates I never objected to meet those of them who had been convicts when assembled on a public occasion' (p. 307). Should we not consider the possibility that an immoral magistrate with a criminal record was a greater threat to New South Wales than an immoral highway commissioner who brought first-hand experience of breaking rocks to the task? The point surely merits discussion. When Marsden launched his Philanthropic Society, part of his South Seas missionary strategy, he did not appear troubled by financial support from Simeon Lord, one of the two emancipists he had objected to working with on the turnpike trust. Indeed, Lord's plans for a flax-growing enterprise in New Zealand dovetailed with his own schemes for a missionary settlement. The key issue was one of status. When Macquarie set up an institution for training Aborigines without consulting Marsden or naming him to its board, the aggrieved chaplain alleged that his omission was 'designedly done to lower me' in colonial public opinion (p. 317). The fact that he had achieved very little in bringing the Gospel to Australia's first peoples was beside the point. On a rare occasion when Sharp criticises his subject ('he had a skin thinner than a contented and effective leader of men should have'), he promptly adds that Marsden was right to distrust those around him (p. 444). Sharp finds Marsden's concern for status 'quite normal behaviour for a member of the political and social elite in such a situation' (p. 467). Once again, it was Marsden himself who showed a rare flash of humble self-knowledge. 'I want more of the pure spirit of religion, that heavenly love, that meekness of wisdom,' he admitted in 1811 (p. 286).

Sharp's reluctance to interrogate Marsden leads him into strong condemnation of the chaplain's foes. Governor Macquarie has usually been portrayed as a beneficent force who arrived at just the moment when the increasing ex-convict population needed to be integrated into the emerging colonial society. Of course, textbook consensus is too often the result of lazy repetition rather than considered analysis: Sharp may be right to challenge Macquarie's place in the national pantheon. But the dismissal hardly seems to spring from extended discussion. 'By attempting to force what time and the ordinary workings of social intercourse 
would bring about, he introduced division and faction, and continually fomented them' (p. 304). These are large claims based upon unproven assumptions. Sensitivity regarding the rattling of the chains remained ingrained in Australian society for a very long time. Sharp's non-judgemental approach to Marsden commits him to severe censure of those with whom his subject clashed.

Seeing early Australia so narrowly through Marsden's eyes tends to obscure the remarkable fact that he appears to have had no vision of the role of ex-convicts in the evolving colonial society. The exponent of a religion that celebrated lost sheep and reclaimed prodigals, he might have been expected to embrace opportunities for rehabilitation. As an agricultural entrepreneur himself, he might equally have welcomed the contribution of those whose misuse of their talents had brought them to the colony. (The architect and convicted forger Francis Greenway, who designed several fine churches, appears once in the book, as 'Greenaway'.) It was hardly a remote and merely theoretical issue for Marsden. His clerical colleague, the Reverend Henry Fulton, had been transported in 1799 after becoming entangled in the Tipperary uprisings of the previous year.(2) Some felt Fulton had been induced to confess under threat of torture, which was likely enough. Marsden thought he was an appropriate choice as chaplain on Norfolk Island, the prison colony's prison colony, but his doubts about Fulton's suitability to function on the mainland were temporarily, and conveniently, waived when he needed a locum during his 1807-9 absence overseas. Yet Marsden seems to have gone no further than admitting that it was 'perhaps' (his emphasis) regrettable 'that though a Convict may be made free of the Country, his conduct constantly correct and exemplary, \& in addition to these, he should prosper and get rich, yet he is never received into the class of Gentlemen' (p. 303). When he briefly touched upon the subject in his evidence to Commissioner Bigge in 1820, he expressed vigorous resentment at the pretensions of successful ex-convicts. Sharp points out that Marsden here simply reflected the standard English insistence upon unforgiving lines of social division. But in accepting appointment as a magistrate, Marsden had specifically rejected advice from his friends back home: 'if they understood the real state of the Colony probably they would change their opinion' (p. 157). The same consideration did not apply to the social integration of ex-convicts.

Of course, it may be riposted that Marsden's thought was mainly focused on the spiritual, although this certainly did not exclude him from involvement in the material.

But Sharp's extensive discussions leave me wondering about two potentially central elements in Marsden's beliefs that might throw light on his view of the World, and maybe also upon the Flesh and the Devil: his attitude to predestination, and his interpretation of Communion.

Was Samuel Marsden a Calvinist? Sharp touches upon this issue at several points, but it seems to remain unresolved. For a rigid believer who held that very few souls were predestined for salvation, New South Wales might have proved a straightforward assignment. The convicts were depraved, the soldiers of the New South Wales Corps were not much better, while the official class mostly rioted in sexual and alcoholic sin. Sharp reports that Marsden 'scarcely mentioned the doctrine of predestination in his many sermons', possibly because it seemed 'inadvisable' to raise the bar for conversion any higher (p. 44). It is difficult to be sure what Marsden believed, not least because, as he cheerfully pointed out, early New South Wales was not fertile ground for religious disputation. 'We are not called upon to defend any particular points of doctrine, but to declare the plain and simple Gospel' (p. 44, repeated p. 157). Elsewhere, Sharp suggests that Marsden ('believer in election as he was') was not unduly discouraged by his failure to make many converts because 'he expected the bulk of mankind to remain unregenerate' (p. 132). 'Your life may end dreadfully here', he thundered to his flock in an undated sermon; 'it will certainly end awfully in Hell' (p. 672). Of course, invocation of Hellfire is not necessarily Calvinistic. Shaken by having to attend his first hanging, he was moved by the 'miserable Situation' of the condemned to 'bless God who had made me to differ' (p. 54), but that attitude perhaps owed more to the Pharisees than to the Genevans.

The hypothesis that Marsden was a thorough-going Calvinist would explain much. It certainly appealed to the Wesleyans, who attributed to him 'Calvinism principles' in 1812. The chaplain, they reported, had 'done little good among the people. Nor does he appear to be anxious about it' (p. 475). (However, the source, an 
educated convict with a marked distaste for the upwardly-mobile Yorkshire blacksmith, poses Sharp's evidential challenge: was criticism of Marsden a reflection of the chaplain's shortcomings, or a measure of the depths to which his detractors would sink?) Marsden's apparent lack of interest in the emancipists would also make sense if he regarded them as merely sinners in smart suits, destined for perdition notwithstanding. Above all, Calvinism would explain his half-hearted approach to the Aboriginal population. For all his enthusiasm about New Zealand, he seems to have expected few converts there too. Sharp concludes that he reported on the Maori practice of cannibalism 'with the cool detachment of one who expected no rapid change' (p. 692).

Holy Communion, under various titles, is one of the central rituals of Christian groups, and one of the two sacraments recognised by Anglicans. Moravians and Methodists used the Love Feast to build solidarity; Anglicans emphasised sacerdotal intervention. All believers agree that the bread they consume represents, in some form, the Body of Christ. On Christmas Day, 1793, deep in the southern oceans, Marsden celebrated the Lord's Supper - his term for the ritual - with his pregnant wife in a cramped cabin. It was obviously important for him to engage in this most basic function of his priestly calling. Yet, thereafter, we hear nothing of a rite that is so central that it seems not to call for elaboration.

Here, again, we might speculate in relation to Marsden's lack of interest in the emancipist community: presumably, he did not see Communion as a group-forging Love Feast. It is worth recalling, too, that the Book of Common Prayer theoretically gave the priest authority to refuse the sacrament, for instance to intending partakers who were in malicious contention with their neighbours - a situation not uncommon in New South Wales. We may assume that Marsden consecrated the elements and handed out the bread and wine in thousands of services. Yet there is neither spiritual nor statistical information to illuminate his discharge of this central priestly function. What did the Eucharist mean to him? With how many communicants did he share it?

The symbolism of the Body of Christ acquired a startling new dimension once missionary work began in New Zealand. It was not merely that Maori sometimes ate people, but that, as Marsden noted in 1823, cannibalism was 'interwoven through the whole of their religious system' (p. 692). (Having himself developed a middle-age spread, the portly chaplain was naturally anxious to discover what prompted Maori to eat human flesh.) He was especially struck by the rituals surrounding the roasting of a dead enemy: 'by eating the flesh and drinking the blood of the departed chief, his system becomes incorporated into their system'. This was, he thought, ' a singular idea'. In a fund-raising report to the Church Missionary Society (CMS), he even speculated that 'one would be led to think that it had been derived from Divine revelation' (pp. 690-1). In the apparent absence of any extended discussion of the Eucharist by Marsden, it is impossible to know whether this comment represented a theologically bold attempt to build a bridge to Maori blood rites, or merely revealed him as another amateur anthropologist speculating that Polynesian culture had Old Testament origins. The CMS evidently concluded that the insight was too much for its subscribers, and edited his comment out of their published appeal.

Traditionally, there has been some disconnection between the Australian Marsden and his New Zealand manifestation. Sharp's deft integration of the two sides of the story is one of the strongest features in the book. It is certainly clear that Marsden's decision to open a new front against the dominion of Satan across the Tasman represented much more than a simple rebound from his frustrations with the old and new populations of New South Wales. He had been involved (at a distance) with missionary activity in Tahiti from his earliest days in Australia, and sought to apply lessons that he felt had been learned from the indifferent success of Christianising activities there.

Unfortunately, the nature of those lessons was not clear. One major conundrum was the relationship between the evangelising mission and the civilising process. Some felt that the Gospel should precede civilisation, others that the Christian message was incomprehensible without modernisation. 'The Arts and Religion should go together', was Marsden's compromise in 1808 (p. 365). Unfortunately, Maori were especially keen to acquire firearms and alcohol, forcing the missionaries - who were dependent upon the goodwill of their 
indigenous neighbours - to make hard choices. Generally, Marsden assumed that civilising the Maori would lead them to embrace the Gospel. However, Sharp argues that 'around 1830, he changed his mind and came to think that Christianity might precede civilisation among the New Zealanders. But it was not, as might be thought, a great change of mind: simply a slight adjustment to circumstances' (p. 685). It might equally be contended that, by 1830, the European impact upon New Zealand was so deep and so disastrous that planning to engage in spiritual activity without taking account of material turmoil was an act of denial.

Two issues of governance were never fully resolved in relation to the New Zealand mission: who exercised internal authority, and how could external protection be secured? Marsden favoured men from backgrounds like his own, skilled artisans with a sense of vocation but lacking the formal education required for ordination. Predictably, these would be unusual personalities, ambitious and assertive. Even Sharp finds it 'surprising' that Marsden did not designate a local head of the mission, despite having argued for such an arrangement in Tahiti. 'I wish them all clearly to interfere with one another as little as possible as they will have no head present to settle any little differences that might arise amongst them' (p. 406). Sharp terms the settlement 'an austere communal regime without any settled means of decision-making laid down' (p. 409). But he stops short of making the obvious point of connection: Marsden refused to create an on-the-ground structure of authority because he intended to control the operation himself. This, too, involved ambiguity, since the CMS in London was ultimately (if, given the distance involved, somewhat theoretically) in control, and 'the missionaries were able to play one off against the other' (p. 411). Micro-management from over 1000 miles away in Australia simply did not work: one disgruntled subordinate complained that the missionaries were charged with saving immortal souls, but not entrusted with control over their own supplies. 'All the difficulties in New Zealand that I have met with have been in governing the Europeans', Marsden complained in 1821 (p. 549). He might perhaps have asked whether he had set himself - and them - an impossible task. Sharp pleads that Marsden became the 'scapegoat' for all the failings of the mission, and the missionaries (p. 560). But since he had chosen to concentrate the responsibility upon himself, it seems fair that he should incur the blame.

If Marsden intentionally ignored the internal decision-making structure of the New Zealand mission, his failure to focus effectively upon the still larger issue of external protection may seem even more unsatisfactory. Theorising about his project in 1808, he insisted upon an Anglican identity, since the established Church could be 'considered as part of the civil Government of N. S. Wales' (p. 363). However, in New Zealand, they would in practice have to rely upon local protection. As Sharp points out, Marsden had in mind Te Pahi, a Bay of Islands chief who was interested in European ways and sympathetic to Christianity. Unfortunately, Te Pahi was murdered by whalers in 1810. The mission went ahead anyway, now relying for protection upon a young chief called Ruatara. 'I could scarcely bring myself to believe that the Divine goodness would remove from the earth such a man whose life was of such infinite importance to his country', Marsden complained, when Ruatara died during his first visit to New Zealand (p. 404). Because Sharp consistently urges us to view Marsden's activities through Marsden's eyes, we are not invited to confront the security issue. The missionaries soon called for a British military detachment to protect them against marauding Maori. Marsden argued for a naval vessel to protect the indigenous population against feral Europeans: a ship would be conveniently mobile, and it would be easier to keep sailors than soldiers away from 'native women' (p. 729). He also hoped that Maori would somehow coalesce into a united and independent polity. Failing that, Marsden favoured the establishment of 'European jurisdiction in New Zealand of a kind sufficient to protect the natives. But he could think of no evident way this might be accomplished' (p. 732).

So massive a book with such a broad range requires an unusually broad and impressive scholarly base. The points on which this reviewer takes issue are mostly minor, and almost all relate to the British and Irish background, not the handling of Australian or New Zealand episodes. It was not strictly true that Nonconformists were banned from attending the ancient English universities: they could study at Cambridge, but not formally graduate. John Macarthur's socially embarrassing background was in Plymouth, not Portsmouth. Vinegar Hill is in County Wexford, not Wicklow. Wales is not a kingdom. These are hardly serious errors. More jarring is Sharp's occasional use of 'United Kingdom' and even 'UK' for Britain. (Britain 
and Ireland did indeed constitute a United Kingdom from 1801, but 'celebrating the United Kingdom's victory at the Battle of Trafalgar' (p. 168) strikes an anachronistic note, as we are reminded by Nelson's famous flag signal, 'England expects'.) More frequent is the use of 'Westminster' as a shorthand for all branches of government, not just parliament. For a few pages, Sharp slips into strange-sounding statements that incoming governors of New South Wales 'took power', but happily this fades. A handful of examples where a cleric is styled 'Rev.' (as in 'Rev. Bain', p. 118) would have been better edited out.

Sharp's massive study does force us to reconsider the intellectual background to early New South Wales and New Zealand. With contact slowly developing from 1769-70, the European phase of the Australian and New Zealand experience may seem unambiguously to belong to 'modern' history, to constitute a familiar prologue to the liberal and secular world of today. Although at one point he likens Marsden to a 'Cromwellian hero' (p. 444), Sharp does not flaunt his own scholarly standing as a distinguished authority on 17th-century religion. Yet the reader can only come away from this work with a strong impression that Marsden consistently measured new experiences against cosmic yardsticks that had been shaped by a much earlier era. Indeed, Sharp sums up his subject as 'a man whose opinions were tolerably coherent and fitting to his times but are increasingly distant from those of most of the globe's people today' (p. 767).

Yet, paradoxically, Marsden adjusted to physical and material change comparable to the bewildering pace of modern-day innovation. At the time of his arrival in 1794, the settler population was around 3,000 - as Sharp points out, similar to the cluster of small West Riding communities in which he had grown up. Marsden perhaps exaggerated in his 1807 claim that a chaplain 'from his local Knowledge and the extensive Information he may obtain thro' other Channels, may be acquainted with the private Principles and moral Character of almost every Prisoner in the Colony' (p. 271). That could hardly have been said 20 years later, when the European population of Australia and New Zealand had reached almost 100,000. While he remained intellectually inflexible, neither modifying his Church principles nor embracing a more forgiving attitude to reformed offenders, Marsden also celebrated the material advance of the colony, waxing eloquent in 1827 'on the contrast that was exhibited before his aged eyes, when compared with the view of the Country 30 years before, at the time of his arrival on these shores' (p. 679).

In this connection, it is worth noting one very basic fact that has been overlooked by all Marsden's biographers: he stayed in Australia. The Oxford Dictionary of National Biography reports his wealth at death as $£ 30,000 \underline{(3)}$, enough to have returned to a comfortable life back home. It is tempting to wonder why he did not do so. Perhaps there were factors that discouraged him, maybe dislike of the more concentrated ecclesiastical authority that he would have encountered in England, or a residual sense of social unease at mixing with squires and erudite fellow clerics. Perhaps he felt tied to New South Wales by his agricultural empire, or by the graves of his children. Most notably, we might point to his sense of responsibility towards his New Zealand mission. The fact that Marsden lived out his life in Australia is so basic that historians have failed to underline the fact that he was one of the few prominent personalities in the early decades of New South Wales history who did not return to Britain.

The meticulous discussion of so much material through so many episodes, locations and decades merits respect. But that respect should manifest itself in engagement with the author's aims and methods. Sharp set out to discuss Marsden's interactions with the World, the Flesh and the Devil. One of these three Sharp himself discounts in his own succinct summary. 'He seems never to have experienced any overriding temptations of the flesh' (p. 765). Rather, it was the weakness of other people's flesh that caused him problems, notably the missionaries Thomas Kendall and William Yate, whose irregular activities in New Zealand spanned a broad range of human sexuality. Nor has Sharp entirely persuaded me of the centrality of the Devil in this story. The Satan who appears so frequently in Marsden's fulminations seems more formulaic than sulphurous. There is no sense of a man locked in personal combat with ensnaring demons. This leaves the World as the central theatre of interaction. Here, as Sharp insists, there is little point in continually dragging Marsden before the bar of History. He should be allowed to speak for himself, and we do indeed need to be reminded that while we recognise much of his vocabulary, the mindset behind his opinions comes from a world that has receded beyond the sympathetic comprehension of most of us. But in 
setting out to interpret Samuel Marsden in his own terms, Sharp raises large issues about biography. Leaving Marsden to define his own role does not help us measure his contribution in those areas where he had little or nothing to say. Of course his focus was upon on the world to come, but this left him with surprisingly few answers to key challenges of the fast-changing Australian and New Zealand reality with which he was so actively engaged. His concern with status probably hampered his ability to conceptualise the emerging society of New South Wales. His emphasis upon salvation contributed to an equally myopic refusal to face issues of governance in an increasingly unstable New Zealand. It ought to be possible to combine a sympathetic appreciation of Marsden's thinking with acknowledgement that his actions were on occasion at odds with the principles adumbrated by his own radical Protestant contemporaries. It should also be possible to offer sympathetic interpretation of Marsden's points of view without endorsing his hostility to the criticisms of others.

To highlight my concerns, I close with Sharp's discussion of Marsden's negative view of the Australian Irish, in an assessment of the colony written in 1807 . Here, and rarely, the author explicitly engages with Yarwood, reproving his forerunner for seeing 'prejudice' in the chaplain's hibernophobia. 'This was not "prejudice": i.e. reaching conclusions before considering the evidence', Sharp retorts. 'His opinion was the fruit of his lived experience' (p. 267). There is indeed a divergence between the predominant meaning of the word and its etymological origin, but some will regard this as mere word-play, and many will feel uneasy that such an interpretation might become a charter for assertive bigotry. Samuel Marsden played a prominent part both in early colonial New South Wales and in the formative decades of the European impact upon Polynesian New Zealand. Historians should indeed seek to comprehend what he thought he was doing, but we cannot allow him to tell his own story without a larger measure of independent commentary than Sharp has attempted.

\section{Notes}

1. A. T. Yarwood, Samuel Marsden: The Great Survivor (Melbourne, 1977).Back to (1)

2. K. J. Cable, 'Fulton, Henry (1761-1840)', Australian Dictionary of Biography (Canberra, 1966) < http://adb.anu.edu.au/biography/fulton-henry-2074/text2593 [2]> [accessed 20 June 2017].Back to (2)

3. A. T. Yarwood, 'Marsden, Samuel (1765-1838)', Oxford Dictionary of National Biography (Oxford, 2004) <http://www.oxforddnb.com/view/article/18101, accessed 24 June 2017 [3]> [accessed 24 July]. Back to (3)

Source URL:https://reviews.history.ac.uk/review/2156

\section{Links}

[1] https://reviews.history.ac.uk/item/251351 [2] http://adb.anu.edu.au/biography/fulton-henry-2074/text2593

[3] http://www.oxforddnb.com/view/article/18101,\%20accessed\%2024\%20June\%202017 